\title{
APAKAH PEREMPUAN INDONESIA TERBELAKANG DALAM ADOPSI INTERNET?*: TEMUAN EMPIRIS
}

\author{
Fathul Wahid \\ Jurusan Teknik Informatika, Fakultas Teknologi Industri, Universitas Islam Indonesia \\ Jl. Kaliurang Km. 14 Yogyakarta 55501, Telp. (0274) 895287, Faks. (0274) 895007 \\ E-mail: fathulwahid@fti.uii.ac.id
}

\begin{abstract}
This research aims to (a) investigate differences in Internet adoption; (b) identify factors affecting Internet adoption; and (c) examine differences of Internet usage pattern between male and female users. Using data from 714 respondents/students with various backgrounds, the research unveils that in general, Internet adoption among female users are lower than that among male users. Using Technology Acceptance Model (TAM), the research also finds that the Internet adoption among female users is affected by perceived ease of use rather than perceived usefulness. On the other hand, the Internet adoption among male users is affected by perceived usefulness rather than perceived ease of use. Male users are found to have a more flexible Internet access venue when compared to female users. The research also gives an evident that Internet usage pattern among male and female users differs. Proportion of female users who use the Internet for chatting and studyrelated activities is significantly larger than that of male users. Conversely, proportion of male users who use the Internet for reading online news, testing and downloading software, shopping, entertainment, seeking job vacancy, and visiting pornographic sites are larger than female users. High cost Internet access and low access speed of the Internet and a lack of English proficiency are identified to be most severe obstacles of the Internet adoption in Indonesia.
\end{abstract}

Keywords: adoption of Internet, women studies, Indonesia.

\section{LATAR BELAKANG}

Dalam beberapa tahun terakhir, jumlah pengguna Internet di Indonesia menunjukkan peningkatan yang cukup menggembirakan. Menurut Asosiasi Penyedia Jasa Internet Indonesia [3], jumlah pelanggan Internet di Indonesia pada beberapa tahun terakhir meningkat cukup pesat; dari 400.000 pelanggan pada tahun 2000 menjadi 1,08 juta pada akhir tahun 2004. Di sisi pengguna, pada tahun 2000 jumlah pengguna Internet hanya mencapai 1,9 juta, namun pada akhir tahun 2004 telah menjadi lebih dari 11,2 juta. Perbedaan antara jumlah pelanggan dan pengguna ini karena satu langganan Internet digunakan oleh lebih dari satu pengguna, seperti langganan Internet di perkantoran dan warung Internet (warnet). Sekitar $80 \%$ pelanggan Internet di Indonesia adalah pelanggan

\footnotetext{
* Penelitian ini didanai oleh Direktorat Jenderal Pendidikan Tinggi, Departemen Pendidikan Nasional melalui Hibah Kajian Wanita tahun 2005.
} 
perusahaan [4] dan sekitar dua-pertiga pengguna mengakses Internet dari warnet [23].

Meskipun perkembangan pertumbuhan pengguna Internet di Indonesia cukup menggembirakan, namun jika dibandingkan dengan negara lain, penetrasi Internet di Indonesia masih sangat rendah. Data bulan September 2005 menunjukkan bahwa pengguna Internet telah mencapai 15,3 juta. Jika pendudukan Indonesia sebanyak 219 juta, maka penetrasi Internet di Indonesia baru $7,0 \%$, lebih rendah rata-rata dunia yang sebesar $14,6 \%$ dan negara-negara Asia yang sebesar 8,9\% (www.internetworldstats. com).

Masalah lain yang menjadi kajian adalah ketimpangan partisipasi antara laki-laki dan perempuan dalam bidang teknologi informasi, termasuk di dalamnya Internet. Secara global, menurut survei yang dilakukan oleh Graphics, Visualization and Usability Centre, Georgia Technology University, pada tahun 1998, sekitar 34\% pengguna Internet adalah perempuan [11]. Di Amerika, persentase pengguna Internet perempuan lebih tinggi (36\%) dibandingkan dengan negara-negara Eropa (18\%) dan negara-negara lainnya (24\%). Angka pengguna Internet perempuan di dunia ini meningkat secara signifikan jika dibandingkan pada 1994 yang hanya 5\%. Survey pada Mei 2003 yang dilakukan oleh Nielsen//NetRatings menunjukkan bahwa persentase perempuan yang online terus meningkat [10]. Persentase pengguna Internet perempuan di Amerika bahkan telah melebihi jumlah pengguna Internet laki-laki, yaitu 52\%. Di Eropa, persentase terbesar pengguna Internet perempuan ditemukan di Inggris dan Swedia, masing-masing sebesar $45 \%$ dan $47 \%$.

Bagaimana dengan pengguna Internet perempuan di Indonesia? Walaupun belum ada penelitian spesifik yang dilakukan dalam konteks ini, namun, banyak pihak percaya bahwa tingkat melek teknologi informasi (information technology literacy) di kalangan perempuan Indonesia masih sangat rendah dibanding lakikali. Untuk menyiasati masalah ini, bahkan, Kementerian Riset dan Teknologi, Kementerian Pemberdayaan Perempuan dan Bappenas memasukan perspektif jender dalam kebijakan dan strategi pembangunan ilmu pengetahuan dan teknologi [30]. Fountain [7] dalam studinya di Amerika menemukan bahwa peran serta perempuan dalam bidang teknologi informasi masih sangat rendah dibanding laki-laki. Kesenjangan antara perempuan dan laki-laki dalam bidang teknologi informasi ini juga mungkin terjadi pada tingkat adopsi Internet. Furuholt, Wahid dan Kristiansen [8] menemukan bahwa 68\% pengguna warung Internet di Indonesia adalah laki-laki.

Penelitian ini secara umum dilakukan untuk memahami adopsi Internet di Indonesia menggunakan Technology Acceptance Model (TAM) yang dikembangkan oleh Davis et al. [5]. TAM merupakan salah satu model penerimaan teknologi yang paling banyak diteliti [18]. Berdasar penelitian komprehensif tentang TAM yang dilakukan oleh Legris, Inghamb dan Collerettec [18], mereka menyimpulkan bahwa secara umum TAM telah terbukti sebagai model teoritis yang bermanfaat untuk memahami dan menjelaskan prilaku penggunaan sistem informasi. Meskipun TAM sudah diperkenalkan pada akhir tahun 1980-an, namun penelitian yang memasukkan variabel jender ke dalam TAM baru dilakukan pada 1997 [9] 
dan tidak banyak penelitian yang secara spesifik memasukkan variabel jender [e.g. 9; 27], apalagi yang dilakukan dalam konteks Indonesia. Secara lebih spesifik, pertanyaan-pertanyaan berikut akan dijawab dengan penelitian ini:

a. Apakah perempuan terbelakang dalam adopsi Internet dibandingkan dengan laki-laki?

b. Apakah terdapat perbedaan faktor-faktor yang mempengaruhi adopsi Internet di kalangan perempuan berbeda dengan laki-laki?

c. Apakah terdapat perbedaan pola penggunaan Internet antara perempuan dan laki-laki?

\section{LANDASAN TEORI}

\subsection{Difusi Inovasi}

Menurut Taylor dan Todd [26], masalah difusi dan adopsi inovasi dapat didekati dari tiga tingkat yang berbeda. Beberapa peneliti mendekatinya dengan pandangan makro dalam sebuah konteks sosial atau sebuah negara [e.g. 14; 16; 17; 26; 29]. Beberapa yang lain meneliti isu ini pada tingkat organisasi [e.g. 12; 22] dan beberapa yang lain lagi melihatnya pada tingkat individu [e.g. 19].

Taylor and Todd [26] membagi penelitian tentang faktor penentu adopsi teknologi informasi ke dalam dua kelompok. Pertama, penelitian yang menggunakan model-model berbasis intensi (intention-based models) dan yang kedua penelitian yang melihat dengan pendekatan difusi inovasi. Penggunaan Technology Acceptance Model (TAM) adalah contoh penelitian pada kelompok pertama, sedang kelompok yang kedua dicontohkan oleh penelitian yang menggunakan teori difusi inovasi yang dikembangkan oleh Roger [24].

\subsection{Technology Acceptance Model}

TAM yang dikembangkan oleh Davis et al. [5] yang ditujukan untuk menjelaskan prilaku penggunaan komputer adalah salah satu model yang paling banyak digunakan dalam penelitian adopsi teknologi. TAM telah mendapatkan banyak pembuktian empirik melalui penelitian-penelitian validasi, aplikasi, dan replikasi [e.g. 18; 19; 22]

TAM dikembangkan berdasar Theory of Reasoned Action (TRA) yang dikembangkan oleh Ajzen dan Fishbein [2] yang masih bersifat umum. TRA dirancang untuk menjelaskan prilaku manusia dan terdiri dari dua faktor yang mempengaruhi intensi prilaku; sikap (attitude) terhadap prilaku dan norma subyektif (subjective norm). Sikap didefinisikan sebagai perasaan/penilaian positif atau negatif seseorang terhadap sebuah prilaku. Norma subyektif adalah persepsi seseorang terhadap tekanan sosial untuk melakukan sebuah prilaku.

TAM terdiri dari dua konstruk, kemudahan penggunaan yang dipersepsikan (perceived ease of use) dan manfaat yang dipersepsikan (perceived usefulness), yang menentukan intensi prilaku (behavioural intention) seseorang untuk menggunakan sebuah teknologi. Intensi prilaku adalah ukuran seberapa besar keinginan seseorang untuk melakukan sebuah tindakan tertentu. TAM ditunjukkan pada Gambar 1. 
Manfaat yang dipersepsikan didefinisikan sebagai "prospective user's subjective probability that using a specific application system will increase this or her job performance within an organizational context" [5, hal. 985]. Penelitianpenelitian sebelumnya yang menggunakan TAM, menemukan bahwa manfaat yang dipersepsikan merupakan faktor penentu adopsi sebuah teknologi [e.g. 5; 19].

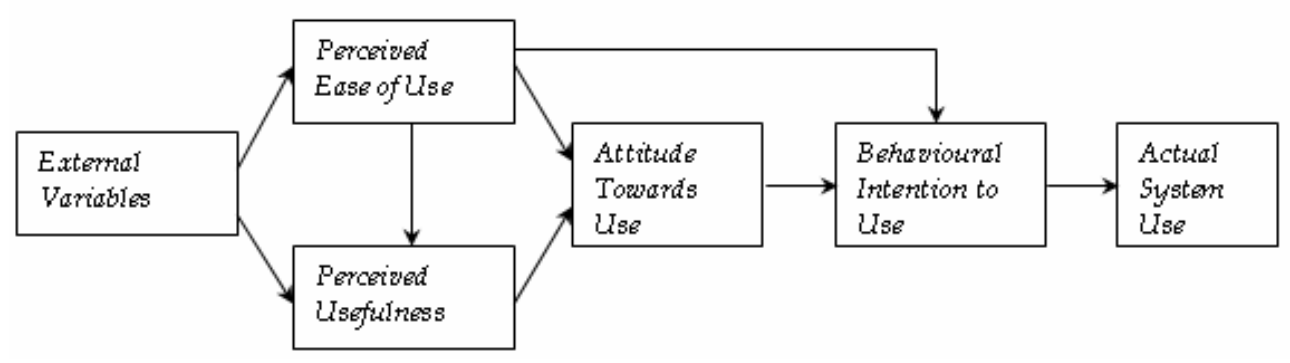

Gambar 1. Technology Acceptance Model

Kemudahan yang dipersepsikan didefinisikan sebagai "the degree to which the prospective user expects the target system to be free of effort" [5, hal. 985]. Dengan mengasumsikan keadaan yang lain sama, maka semakin mudah sebuat teknologi digunakan, semakin besar kemungkinan teknologi tersebut diadopsi atau diterima oleh pengguna.

Penelitian yang dilakukan oleh Venkatesh dan Morris [27] di Amerika menemukan bahwa dalam membuat keputusan untuk menggunakan sebuah teknologi, laki-laki lebih dipengaruhi oleh persepsinya terhadap manfaat teknologi tersebut. Teori-teori psikologi dan budaya sebelumnya juga mendukung temuan ini. Misalnya, Hofstede [13] menemukan bahwa laki-laki menganggap kemajuan dan daya hasil lebih penting daripada anggapan perempuan. Selanjutnya, Minton dan Schneider[20]seperti dikutip dalam Venkatesh dan Morris [27] menyatakan bahwa laki-laki cenderung lebih berorietasi kepada tugas yang diberikan daripada perempuan. Dalam konteks ini orientasi tugas dapat diartikan sebagai penyelesaian tugas-tugas yang dibebankan yang mungkin membutuhkan teknologi.

Sebaliknya, di kalangan perempuan pengaruh kemudahan yang dipersepsikan terhadap adopsi lebih tinggi daripada pegaruhnya di kalangan lakilaki [27]. Tingkat kemahiran teknologi informasi (self-efficacy) yang rendah di kalangan perempuan mendukung temuan ini [27]. Namun perlu dicatat di sini, tingkat kemahiran tidaklah satu-satunya penyebab lebih rendahnya adopsi Internet di kalangan perempuan di bandingkan laki-laki. Faktor-faktor sosial dan kultural (seperti bagaimana perempuan diposisikan dalam sebuah masyarakat) juga berpengaruh dalam konteks adopsi teknologi [16; 25].

Selanjutnya, TAM juga menunjukkan bahwa manfaat yang dipersepsikan akan dipengaruhi oleh kemudahan penggunaan yang dipersepsikan, karena jika 
kondisi yang lain tetap, jika semakin mudah sebuah teknologi digunakan, maka teknologi tersebut akan dipersepsikan semakin bermanfaat.

TAM juga mengasumsikan adanya efek variabel eksternal terhadap intensi yang diperantarai oleh manfaat yang dipersepsikan dan kemudahan yang dipersepsikan. Variabel eksternal ini dapat berupa karakteristik rancangan sistem, pelatihan, dokumentasi, karakteristik pengambil keputusan yang mungkin mempengaruhi penggunakan [5]. Pada pengujian praktis, variabel eksternal dapat maujud dalam berbagai variabel yang berbeda, seperti jender, pengalaman, dukungan transisi, dan norma subyektif [18]. Namun, seperti disinggung sebelumnya, pemasukan variabel jender ke dalam TAM hanya ditemukan dalam sedikit penelitian [e.g. 9; 27].

Pemasukan variabel eksternal juga didukung oleh penelitian-penelitian sebelumnya yang menemukan bahwa faktor demografi (seperti jenis kelamin, tingkat pendidikan, dan tingkat penghasilan) mempengaruhi adopsi teknologi. Du [6] misalnya, menemukan bahwa pengguna Internet di Cina sebagian besar adalah kalangan muda, laki-laki, terpelajar, lajang, dan mempunyai penghasilan yang cukup tinggi. Masih di Cina, Abbot [1] menemukan bahwa persentase pengguna laki-laki sebesar 79\%. Warf dan Grimes [28] menemukan bahwa sebagian besar pengguna Internet di Amerika adalah ras kulit putih, kelas menengah, terpelajar, dan mempunyai pekerjaan yang membutuhkan ijazah universitas.

\subsection{Hipotesis}

Berdasar teori dan temuan penelitian sebelumnya, secara spesifik, hipotesishipotesis berikut akan dibuktikan dalam penelitian ini.

Hipotesis 1: Laki-laki lebih awal mengadopsi Internet dibandingkan dengan perempuan.

Hipotesis 2: Tingkat adopsi Internet pengguna perempuan lebih rendah dibandingkan dengan adopsi pengguna laki-laki.

Hipotesis 3: Laki-laki mempunyai tempat mengakses Internet lebih bervariasi dibandingkan dengan perempuan.

Hipotesis 4: Pengaruh manfaat yang dipersepsikan terhadap intensi menggunakan Internet di kalangan laki-laki lebih kuat daripada pengaruhnya di kalangan perempuan.

Hipotesis 5: Pengaruh kemudahan yang dipersepsikan terhadap intensi menggunakan Internet di kalangan perempuan lebih kuat daripada pengaruhnya di kalangan laki-laki.

Hipotesis 6: Terdapat perbedaan pola penggunaan Internet antara perempuan dan laki-laki.

\section{METODE PENELITIAN}

\subsection{Instrumen Penelitian}

Instrumen penelitian terdiri dari beberapa bagian; demografi dan pola penggunaan Internet, kemampuan personal (self-efficacy), adopsi Internet, dan hambatan penggunaan Internet. Sebagian besar pertanyaan dikembangkan khusus 
untuk penelitian ini, kecuali instrumen untuk mengukur variabel manfaat, kemudahan, dan intensi yang diadaptasi dari instrumen yang digunakan oleh Venkatesh dan Morris [27]. Pertanyaan untuk mengukur manfaat, kemudahan, dan intensi dirangkum pada Tabel 1.

Tabel 1. Pertanyaan untuk mengukur manfaat, kemudahan, dan intensi

\begin{tabular}{|c|l|}
\hline Kode & Pertanyaan \\
\hline U1 & $\begin{array}{l}\text { Penggunaan Internet dalam pekerjaan/studi saya akan menjadikan saya lebih } \\
\text { cepat dalam menyelesaikan tugas. }\end{array}$ \\
\hline U2 & Penggunaan Internet akan meningkatkan kinerja (prestasi) kerja/studi saya \\
\hline U3 & $\begin{array}{l}\text { Penggunaan Internet dalam pekerjaan/studi saya akan meningkatkan } \\
\text { produktivitas saya. }\end{array}$ \\
\hline U4 & Penggunaan Internet akan meningkatkan efektivitas dalam pekerjaan/studi saya. \\
\hline U5 & Penggunaan Internet akan memudahkan saya dalam melakukan pekerjaan/studi. \\
\hline U6 & Saya melihat bahwa Internet bermanfaat dalam pekerjaan/studi saya. \\
\hline E1 & Mempelajari pengoperasian Internet adalah mudah bagi saya. \\
\hline E2 & Internet memudahkan saya untuk melakukan apa yang ingin saya lakukan. \\
\hline E3 & Interaksi saya dengan Internet jelas dan mudah dipahami. \\
\hline E4 & Saya dapat berinteraksi dengan Internet dengan fleksibel. \\
\hline E5 & Mudah bagi saya untuk menjadi trampil dalam penggunaan Internet. \\
\hline E6 & Saya melihat bahwa Internet mudah digunakan. \\
\hline I1 & Seandainya saya mempunyai akses ke Internet. saya akan menggunakannya. \\
\hline I2 & Jika saya diberi akses ke Internet. saya kira bahwa saya akan menggunakannya. \\
\hline
\end{tabular}

Kemampuan personal diukur dengan tiga pertanyaan yang masing-masing terkait dengan pengetahuan tentang komputer, kemampuan bahasa Inggris, dan pengetahuan tentang Internet. Adopsi Internet diukur dengan melihat intensitas penggunaan Internet dalam jangka waktu tertentu dalam jam.

\subsection{Pengumpulan Data}

Sampel penelitian ini adalah mahasiswa dari berbagai latar belakang jurusan, angkatan dan perguruan tinggi. Metode sampling yang digunakan adalah convenience sampling. Namun demikian, untuk menjamin keragaman latar belakang responden, pengumpulan data akan dilakukan pada tempat-tempat publik di lingkungan kampus, seperti kantin, perpustakaan, dan tempat-tempat aktivitas mahasiswa.

\subsection{Analisis Data}

Sebelum data dianalisis, uji dilakukan untuk menjamin validitas dan reliabilitas instrumen yang digunakan. Uji validitas dan reliabilitas ini dilakukan untuk variabel yang pengukurannya menggunakan beberapa pertanyaan.

Analisis regresi akan digunakan untuk melihat pengaruh dari variabelvariabel independen (yaitu manfaat, kemudahan, kemampuan personal) secara bersama-sama terhadap variabel dependen, intensi adopsi Internet. Analisis regresi ini juga akan mempertimbangkan uji asumsi klasik, seperti asumsi normalitas, tidak adanya outlier dalam data, dan tidak adanya multikolinieritas. 
Untuk melihat perbedaan antar berbagai variabel antara responden perempuan dan laki-laki, uji $t$ untuk sampel independen (independent samples $t$-test) akan dilakukan. Semua uji statistik akan dilakukan pada tingkat signifikansi 1\% dan $5 \%$. Karena sebagian besar pertanyaan dalam instrumen penelitian adalah pertanyaan tertutup, maka paket software statistik SPSS akan digunakan untuk memudahkan analisis data.

\section{HASIL}

\subsection{Uji Validitas dan Reliabilitas Instrumen}

Validitas instrumen penelitian diuji menggunakan analisis faktor, sedang reliabilitas insrumen ditentukan menggunakan nilai alfa Cronbach. Hasil uji validitas dan reliabilitas instrumen dirangkum pada Tabel 2. Bobot hasil faktor analisis menunjukkan bahwa item kuesioner terkelompok seperti rancangan awal penelitian. Seperti terlihat pada Tabel 2, semua nilai alfa Cronbach lebih tinggi dari 0,6 yang merupakan batas bawah penerimaan validitas [21]. Dengan demikian dapat disimpulkan bahwa instrumen penelitian valid dan reliabel.

Tabel 2. Hasil uji validitas dan reliabilitas instrumen

\begin{tabular}{|c|c|c|c|c|c|c|}
\hline \multirow{2}{*}{ Kode item } & \multirow{2}{*}{ Rata-rata } & \multirow{2}{*}{ Simpangan baku } & \multirow{2}{*}{$\begin{array}{c}\text { Alfa } \\
\text { Cronbach }\end{array}$} & \multicolumn{3}{|c|}{ Bobot } \\
\cline { 5 - 7 } Manfaat & 3,68 & 0,78 & 0,83 & Manfaat & Kemudahan & Intensi \\
U1 & & & & 0,70 & & \\
U2 & & & & 0,74 & \\
U3 & & & & 0,60 & & \\
U4 & & & & 0,78 & & \\
U5 & & & 0,73 & & \\
U6 & & & 0,84 & & & \\
\hline Kemudahan & 3,51 & 0,77 & & & 0,63 & \\
E1 & & & & & 0,49 & \\
E2 & & & & & 0,82 & \\
E3 & & & & & 0,79 & \\
E4 & & & & & & \\
E5 & & & & & & \\
E6 & & & & & & \\
\hline Intensi & 4,18 & 0,85 & & & & \\
I1 & & & & & & \\
I2 & & & & & & \\
\hline
\end{tabular}

Catatan: Metode ekstraksi: principal component analysis dengan metode rotasi varimax dengan normalisasi Kaiser.

\subsection{Demografi responden}

Dari sebanyak 800 kuesioner yang dibagikan, sebanyak 714 responden (89,3\% response rate) mengembalikan dan semuanya dapat dianalisis lebih lanjut. Demografi responden dirangkum pada Tabel 3. Latar belakang pendidikan sebagian besar $(25,63 \%)$ responden adalah teknik informatika. Jika dikelompokkan berdasar rumpun ilmu, sebanyak 478 atau $66,9 \%$ responden mempunyai latar 
belakang pendidikan teknik. Lebih dari separoh $(56,70 \%)$ adalah responden perempuan.

Umur rata-rata responden adalah 21,77 tahun. Sebagian besar (80,95\%) respoden berumur antara 21-25 tahun dan hanya 0,70\% yang berumur di atas 25 tahun. Pengeluaran rata-rata per bulan responden $\mathrm{Rp} 455.700$ dengan rentang antara Rp 50.000 sampai $\mathrm{Rp} 1.500 .000$. Pengeluaran sebagian besar $(71,00 \%)$ responden antara $\operatorname{Rp} 250.000-500.000$ dan hanya sedikit (7,05\% dan 8,31\%) yang mempunyai pengeluaran lebih dari Rp 750.000 atau kurang dari $\operatorname{Rp} 250.000$.

Tabel 3. Demografi responden

\begin{tabular}{|c|c|c|}
\hline \multirow{2}{*}{$\begin{array}{c}\text { Variabel } \\
\text { Latar belakang pendidikan }\end{array}$} & $n$ & $\%$ \\
\hline & & \\
\hline - Teknik Informatika & 183 & 25,63 \\
\hline - Teknik Industri & 76 & 10,64 \\
\hline - Teknik Kimia & 46 & 6,44 \\
\hline - Teknik Elektro & 36 & 5,04 \\
\hline - Teknik Mesin & 24 & 3,36 \\
\hline - Teknik Sipil & 65 & 9,10 \\
\hline - Teknik Lingkungan & 14 & 1,96 \\
\hline - Teknik Arsitektur & 34 & 4,76 \\
\hline - Kimia & 15 & 2,10 \\
\hline - Farmasi & 39 & 5,46 \\
\hline - Statistik & 14 & 1,96 \\
\hline - Kedokteran & 32 & 4,48 \\
\hline - Psikologi & 64 & 8,96 \\
\hline - Manajemen & 37 & 5,18 \\
\hline - Akuntansi & 19 & 2,66 \\
\hline - Studi Pembangunan & 3 & 0,42 \\
\hline - Hukum & 8 & 1,12 \\
\hline - Syariah & 5 & 0,70 \\
\hline Jender & & \\
\hline - Laki-laki & 405 & 56,70 \\
\hline - Perempuan & 309 & 43,30 \\
\hline Umur (tahun) & & \\
\hline$-<=20$ & 131 & 18,35 \\
\hline$-21-25$ & 578 & 80,95 \\
\hline$->=26$ & 5 & 0,70 \\
\hline Pengeluaran per bulan (Rp) & & \\
\hline$-<250.000$ & 53 & 8,31 \\
\hline$-250.000-500.000$ & 453 & 71,00 \\
\hline - 500.001-750.000 & 87 & 13,64 \\
\hline$->750.000$ & 45 & 7,05 \\
\hline
\end{tabular}




\subsection{Uji hipotesis}

Pada bagian ini setiap hipotesis yang telah dirumuskan diuji satu per satu.

Hipotesis 1

Perbandingan distribusi lama adopsi Internet responden laki-laki dan perempuan ditunjukkan pada Tabel 4. Responden rata-rata telah menggunakan Internet selama 4,75 tahun.

Tabel 4. Lama adopsi Internet

\begin{tabular}{|c|c|c|c|c|c|c|c|}
\hline $\begin{array}{c}\text { Lama adopsi } \\
\text { Internet } \\
\text { (tahun) }\end{array}$ & \multirow{2}{*}{$\begin{array}{c}\text { Sejak } \\
\text { tahun }\end{array}$} & \multicolumn{3}{|c|}{$n$} & \multicolumn{3}{c|}{$\%$} \\
\cline { 5 - 8 } & & Laki-laki & Perempuan & Total & Laki-laki & Perempuan & Total \\
\hline \hline 1 & 2003 & 4 & 2 & 6 & 0,57 & 0,29 & 0,86 \\
\hline 2 & 2002 & 11 & 14 & 25 & 1,57 & 2,00 & 3,57 \\
\hline 3 & 2001 & 32 & 40 & 72 & 4,56 & 5,71 & 10,27 \\
\hline 4 & 2000 & 122 & 110 & 232 & 17,40 & 15,69 & 33,10 \\
\hline 5 & 1999 & 123 & 76 & 199 & 17,55 & 10,84 & 28,39 \\
\hline 6 & 1998 & 55 & 43 & 98 & 7,85 & 6,13 & 13,98 \\
\hline 7 & 1997 & 33 & 11 & 44 & 4,71 & 1,57 & 6,28 \\
\hline 8 & 1996 & 10 & 1 & 11 & 1,43 & 0,14 & 1,57 \\
\hline 9 & 1995 & 8 & 1 & 9 & 1,14 & 0,14 & 1,28 \\
\hline 10 & 1994 & 0 & 1 & 1 & 0,00 & 0,14 & 0,14 \\
\hline 11 & 1993 & 2 & 2 & 4 & 0,29 & 0,29 & 0,57 \\
\hline 12 & 1992 & 4 & 2 & 6 & 0,57 & 0,29 & 0,86 \\
\hline 13 & 1991 & 11 & 14 & 25 & 1,57 & 2,00 & 3,57 \\
\hline 14 & 1990 & 32 & 40 & 72 & 4,56 & 5,71 & 10,27 \\
\hline 15 & 1989 & 122 & 110 & 232 & 17,40 & 15,69 & 33,10 \\
\hline
\end{tabular}

Uji perbandingan rata-rata dengan independent samples $t$-test menunjukkan bahwa laki-laki (rata-rata $=4,92 ; \mathrm{sd}=1,56)$ secara signifikan $(t=3,32 ; p<0,001)$ lebih awal mengadopsi Internet dibandingkan dengan perempuan (rata-rata $=4,52$; $s d=1,51)$. Namun demikian, uji serupa pada rata-rata umur sewaktu mengadopsi Internet pertama kali menunjukkan bahwa tidak terdapat perbedaan yang signifikan $(p>0,1)$ antara laki-laki (rata-rata=17,09; $s d=2,13$ ) dan perempuan (ratarata=19,69; sd=1,7). Dengan demikian hipotesis 1 yang menyatakan bahwa lakilaki mangadopsi Internet lebih awal dibandingkan dengan perempuan tidak terbukti.

\section{Hipotesis 2}

Uji perbandingan rata-rata tingkat adopsi Internet yang diukur dengan lama penggunaan dalam jam per minggu menunjukkan bahwa laki-laki (rata-rata $=5,32$; $\mathrm{sd}=6,91$ jam per minggu) mengggunakan Internet lebih lama secara signifikan $(t=3,07 ; \quad p<0,01)$ dibandingkan perempuan (rata-rata $=4,04 ; \quad s d=3,95$ jam per minggu). Berdasar uji ini, hipotesis 2 yang menyatakan tingkat adopsi Internet pengguna perempuan lebih rendah dibandingkan dengan adopsi pengguna lakilaki terbukti. 


\section{Hipotesis 3}

Uji perbandingan rata-rata menunjukkan bahwa laki-laki (rata-rata $=2,11$ tempat) mempunyai tempat mengakses Internet yang lebih variatif $(t=2,75 ; p<0,01)$ dibandingkan perempuan (rata-rata $=2,02$ ). Hal ini menunjukkan bahwa akses lakilaki untuk menggunakan Internet lebih baik baik dibandingkan perempuan. Dengan demikian, hipotesis 3 yang menyatakan bahwa laki-laki mempunyai tempat mengakses Internet lebih bervariasi dibandingkan dengan perempuan terbukti.

\section{Hipotesis 4 dan 5}

Dua buah model regresi masing-masing untuk responden laki-laki dan perempuan dengan variabel dependen intensi dan variabel independen manfaat dan kemudahan. Analisis regresi dilakukan dengan metode stepwise yang memungkinkan identifikasi variabel independen yang paling mempengaruhi variabel dependen. Tabel 5 merangkum hasil analisis regresi. Terlihat pada Tabel 5 bahwa untuk nilai beta untuk variabel manfaat untuk laki-laki $(0,29)$ lebih besar dari pada nilai beta untuk perempuan $(0,23)$. Sebaliknya, nilai beta untuk kemudahan untuk laki-laki $(0,28)$ lebih kecil dari pada nilai beta untuk perempuan $(0,41)$. Disamping itu, pada pengguna Internet laki-laki, nilai beta untuk variabel manfaat $(0,29)$ lebih besar daripada nilai beta untuk variabel kemudahan $(0,28)$. Hal yang sebaliknya terjadi pada pengguna Internet perempuan, di mana nilai beta untuk variabel kemudahan $(0,41)$ lebih besar daripada nilai beta untuk variabel manfaat $(0,23)$.

Tabel 5. Hasil analisis regresi

\begin{tabular}{|l|c|c|c|c|}
\hline \multirow{2}{*}{ Variabel } & \multicolumn{2}{|c|}{ Laki-laki } & \multicolumn{2}{c|}{ Perempuan } \\
\cline { 2 - 5 } & Beta & $\mathrm{t}$ & Beta & $\mathrm{t}$ \\
\hline Manfaat & 0,29 & $5,33^{*}$ & 0,23 & $3,97^{*}$ \\
\hline Kemudahan & 0,28 & $5,18^{*}$ & 0,41 & $7,02^{*}$ \\
\hline Ringkasan model & \multicolumn{2}{c|}{0,33} \\
\hline Adj-R2 & \multicolumn{2}{|c|}{0,24} & \multicolumn{2}{c|}{$70,20^{*}$} \\
\hline F & \multicolumn{2}{|c|}{$60,61^{*}$} & \multicolumn{2}{c|}{} \\
\hline
\end{tabular}

Catatan: *Signifikan pada level 0,01

Statistik ini menjelaskan bahwa pada pengguna Internet laki-laki, manfaat Internet yang dipersepsikan lebih menentukan dalam intensi penggunaan Internet daripada kemudahan yang dipersepsikan. Sebaliknya, pada pengguna Internet perempuan, kemudahan penggunaan Internet yang dipersepsikan lebih menentukan dalam intensi penggunaan Internet daripada manfaat yang dipersepsikan. Temuan ini konsisten dengan temuan penelitian yang dilakukan oleh Venkatesh dan Morris [27].

Dengan demikian, hipotesis 4 yang menyatakan bahwa pengaruh manfaat yang dipersepsikan terhadap intensi menggunakan Internet di kalangan laki-laki lebih kuat daripada pengaruhnya di kalangan perempuan terbukti. Hipotesis 5 yang menyatakan bahwa pengaruh kemudahan yang dipersepsikan terhadap 
intensi menggunakan Internet di kalangan perempuan lebih kuat daripada pengaruhnya di kalangan laki-laki juga terbukti.

\section{Hipotesis 6}

Uji perbandingan rata-rata dilakukan untuk melihat perbedaan pola penggunaan Internet antara pengguna laki-laki dan pengguna perempuan (lihat Tabel 6). Terlihat bahwa terdapat perbedaan pola penggunaan yang signifikan. Proporsi perempuan yang menggunakan Internet untuk chatting dan terkait studi lebih banyak dibandingkan proporsi laki-laki. Sebaliknya, proporsi laki-laki yang menggunakan Internet untuk membaca berita online, mencoba software, mendownload software, berbelanja, mencari hiburan, mencari informasi pekerjaan, dan mengunjungisitus pornografi lebih tinggi dibanding proporsi pengguna Internet perempuan.

Tabel 6. Pola penggunaan Internet

\begin{tabular}{|c|c|c|c|c|c|c|c|}
\hline \multirow{2}{*}{ No } & \multirow{2}{*}{ Penggunaan Internet } & \multicolumn{2}{|c|}{ Laki-laki } & \multicolumn{2}{|c|}{ Perempuan } & \multirow{2}{*}{\multicolumn{2}{|c|}{$t$}} \\
\hline & & $n$ & $\%$ & $n$ & $\%$ & & \\
\hline 1 & E-mail & 325 & 80,25 & 247 & 79,94 & 0,10 & \\
\hline 2 & Chatting & 234 & 57,78 & 204 & 66,02 & $-2,25$ & ** \\
\hline 3 & Mengakses situs universitas & 328 & 80,99 & 246 & 79,61 & 0,46 & \\
\hline 4 & Membaca media massa online & 255 & 62,96 & 170 & 55,02 & 2,15 & ** \\
\hline 5 & Mencoba software & 99 & 24,44 & 23 & 7,44 & 6,13 & $* * *$ \\
\hline 6 & Mendownload software & 191 & 47,16 & 68 & 22,01 & 7,16 & $* * *$ \\
\hline 7 & Berbelanja & 22 & 5,43 & 8 & 2,59 & 1,88 & * \\
\hline 8 & Mencari hiburan & 293 & 72,35 & 202 & 65,37 & 2,00 & ** \\
\hline 9 & Terkait studi & 348 & 85,93 & 295 & 95,47 & $-4,27$ & $* * *$ \\
\hline 10 & Mencari informasi pekerjaan & 130 & 32,10 & 73 & 23,62 & 2,49 & ** \\
\hline 11 & Mengunjungi situs pornografi & 106 & 26,17 & 12 & 3,88 & 8,31 & $* * *$ \\
\hline
\end{tabular}

Catatan: ${ }^{*} p<0,1 ;{ }^{* *} p<0,05$; ${ }^{* * *} p<0,01$;

Tabel 7. Rangkuman hasil penelitian

\begin{tabular}{|c|l|l|}
\hline No & Hipotesis & Hasil \\
\hline 1 & $\begin{array}{l}\text { Laki-laki lebih awal mengadopsi Internet dibandingkan dengan } \\
\text { perempuan. }\end{array}$ & Tidak terbukti \\
\hline 2 & $\begin{array}{l}\text { Tingkat adopsi Internet pengguna perempuan lebih rendah } \\
\text { dibandingkan dengan adopsi pengguna laki-laki. }\end{array}$ & Terbukti \\
\hline 3 & $\begin{array}{l}\text { Laki-laki mempunyai tempat mengakses Internet lebih bervariasi } \\
\text { dibandingkan dengan perempuan. }\end{array}$ & Terbukti \\
\hline 4 & $\begin{array}{l}\text { Pengaruh manfaat yang dipersepsikan terhadap intensi } \\
\text { menggunakan Internet di kalangan laki-laki lebih kuat daripada } \\
\text { pengaruhnya di kalangan perempuan. }\end{array}$ & $\begin{array}{l}\text { Terbukti } \\
\text { mengaruh kemudahan yang dipersepsikan terhadap intensi } \\
\text { daripada pengaruhnya di kalangan laki-laki. }\end{array}$ \\
\hline 6 & $\begin{array}{l}\text { Terdapat perbedaan pola penggunaan Internet antara perempuan } \\
\text { dan laki-laki. }\end{array}$ & Terbukti \\
\hline
\end{tabular}


Dengan demikian, hipotesis 6 yang menyatakan bahwa terdapat perbedaan pola penggunaan Internet antara perempuan dan laki-laki terbukti. Secara keseluruhan, dari enam hipotesis yang dirumuskan, lima di antaranya terbukti. Rangkuman hasil penelitian ditunjukkan pada

Tabel 7.

Penelitian juga mengidentifikasi hambatan adopsi Internet seperti yang dirangkum pada Tabel 8. Biaya yang mahal dan akses yang lambat merupakan dua hambatan utama adopsi Internet. Penguasan Bahasa Inggris yang masih rendah juga menjadi hambatan dalam adopsi Internet. Bahasa Inggris sampai saat ini masih merupakan bahasa sebagian besar konten di Internet.

Tabel 8. Hambatan adopsi Internet

\begin{tabular}{|c|l|c|c|c|}
\hline \multirow{2}{*}{ No } & \multirow{2}{*}{ Hambatan } & \multicolumn{3}{|c|}{ Nilai rata-rata } \\
\cline { 2 - 4 } & & Semua & Laki-laki & Perempuan \\
\hline 1 & Biaya yang mahal & 2,21 & 2,13 & 2,32 \\
\hline 2 & Bahasa Inggris kurang & 3,16 & 3,17 & 3,13 \\
\hline 3 & Terbatasnya situs Indonesia & 3,65 & 3,54 & 3,78 \\
\hline 4 & Tidak punya waktu luang & 3,65 & 3,58 & 3,73 \\
\hline 5 & Bahaya Internet & 3,61 & 3,63 & 3,59 \\
\hline 6 & Belum perlu & 3,71 & 3,57 & 3,93 \\
\hline 7 & Infrastruktur tidak memadai & 3,37 & 3,25 & 3,57 \\
\hline 8 & Akses lambat & 2,96 & 2,84 & 3,12 \\
\hline 9 & Tidak ada manfaat & 4,55 & 4,13 & 5,13 \\
\hline
\end{tabular}

Catatan: Nilai rata-rata menunjukkan penilaian terhadap peringkat keseriusan hambatan. Semakin kecil nilai rata-rata, semakin serius hambatan tersebut.

\section{PEMBAHASAN}

Pembahasan dilakukan dengan mengacu kepada rumusan masalah yang telah dituliskan pada awal tulisan ini.

Apakah perempuan terbelakang dalam adopsi Internet dibandingkan dengan laki-laki?

Meskipun penelitian ini tidak membuktikan bahwa laki-laki lebih awal atau pada usia lebih muda dalam mengadopsi Internet dibandingkan perempuan, namun penelitian menunjukkan bahwa tingkat adopsi, yang diukur dalam jam per minggu, pengguna Internet perempuan secara signifikan lebih rendah dibandingkan laki-laki. Hal ini menguatkan dugaan yang selama ini mengemuka, bahwa perempuan cenderung tertinggal dalam adopsi teknologi informasi.

Penelitian ini juga menemukan bahwa dalam adopsi Internet, laki-laki mempunyai tempat akses yang lebih variatif dibandingkan perempuan. Hal ini juga yang nampaknya menyebabkan laki-laki mengakses Internet lebih lama daripada perempuan. 
Apakah terdapat perbedaan faktor-faktor yang mempengaruhi adopsi Internet di kalangan perempuan berbeda dengan laki-laki?

Penelitian menemukan bahwa manfaat Internat yang dipersesikan oleh lakilaki lebih berpengaruh dalam adopsi Internet daripada kemudahan penggunaannya. Kasus sebaliknya terjadi di pengguna Internet perempuan. Hal ini nampaknya tidak dipengaruhi oleh ketrampilan teknis yang dimiliki laki-laki. Laki-laki mempunyai kemampuan komputer (rata-rata=3,24; sd=0,87; $1=$ pemula; $5=$ mahir) dan Internet (rata-rata $=3,16 ; \mathrm{sd}=0,86$ ) yang secara signifikan (masingmasing pada $p<0,05$ dan $p<0,01)$ lebih tinggi dibandingkan perempuan (kemampuan komputer; rata-rata $=3,08$; $\mathrm{sd}=0,74$; dan kemampuan Internet; ratarata=3,26; sd=0,75). Ketrampilan teknis seperti ini relatif mudah dikuasai jika tidak digunakan untuk kegiatan di Internet yang cukup kompleks. Pengetahuan tentang e-mail, chatting, dan browsing dapat dikuasai dengan mudah.

Berbeda halnya jika terkait dengan Bahasa Inggris yang merupakan bahasa yang paling banyak mendominasi konten Internet. Perempuan secara signifikan $(p<0,05)$ mempunyai kemampuan Bahasa Inggris yang lebih baik (rata-rata $=3,07$; $\mathrm{sd}=0,79)$ dibandingkan laki-laki (rata-rata=2,91; $\mathrm{sd}=0,95$ ). Mungkin inilah alasan mengapa adopsi Internet perempuan lebih banyak dipengaruhi oleh kemudahan daripada manfaat. Seseorang yang mempunyai kemampuan Bahasa Inggris baik dipastikan akan lebih mudah menggunakan Internet dibandingkan. Temuan ini konsisten dengan temuan penelitian yang dilakukan oleh Venkatesh dan Morris [27].

Apakah terdapat perbedaan pola penggunaan Internet antara perempuan dan laki-laki?

Penelitian ini juga menemukan bahwa terdapat pola penggunakan yang berbeda antara perempuan dan laki-laki. Penggunaan Internet untuk chatting dan terkait dengan studi lebih diminati oleh pengguna perempuan, sedang membaca berita online, penggunaan yang lebih bersifat teknis (seperti mencoba software dan mendownload software), dan penggunaan untuk hiburan (seperti mencari hiburan dan mengunjungi situs pornografi) lebih diminati laki-laki. Temuan ini konsisten dengan penelitian yang dilakukan oleh Kristiansen, Furuholt, dan Wahid [15] yang menemukan adanya perbedaan faktor demografis dalam menentukan pola penggunaan Internet. Penggunaan Internet untuk game komputer dan mengunjungi situs pornografi di kalangan laki-laki secara signifikan lebih besar dibandingkan perempuan.

\section{SIMPULAN DAN SARAN}

\subsection{Simpulan}

Beberapa simpulan dapat ditarik dari analisis di atas. Pertama, tingkat adopsi pengguna Internet laki-laki di Indonesia lebih tinggi dibandingkan tingkat adopsi di kalangan perempuan. Hal ini sangat mungkin dipengaruhi oleh fleksibiltas akses yang dimiliki laki-laki lebih tinggi dibandingkan yang dimiliki perempuan. Dengan demikian, temuan penelitian ini juga menjadi bukti empiris 
atas klaim yang banyak beredar bahwa di Indonesia, adopsi teknologi informasi di kalangan perempuan cenderung tertinggal.

Kedua, terdapat perbedaan faktor yang mempengaruhi adopsi Internet di kalangan laki-laki dan perempuan. Manfaat yang dipersepsikan lebih mempengaruhi laki-laki dalam mengadopsi Internet, sedang adopsi di kalangan pengguna perempuan lebih dipengaruhi oleh kemudahan yang dipersepsikan. Kemampuan teknis laki-laki yang lebih tinggi dibandingkan kemampuan dan kemampuan Bahasa Inggris perempuan yang lebih tinggi dibandingkan kemampuan laki-laki merupakan salah satu penjelas untuk temuan ini.

Ketiga, pola penggunaan Internet di kalangan pengguna laki-laki berbeda dengan pola di kalangan pengguna perempuan. Penggunaan Internet untuk keperluan terkait studi, e-mail, dan mengakses situs universitas, membaca media massa online, serta chatting merupakan yang dominan di kalangan laki-laki. Di kalangan perempuan, penggunaan Internet yang paling dominan adalah untuk keperluan terkait studi, e-mail, mengakses situs universitas, dan chatting. Meskipun terdapat kemiripan dalam hal akses, namun secara umum tingkat penggunaan di kalangan perempuan lebih rendah dibandingkan tingkat penggunaan di kalangan laki-laki.

Keempat, tingkat adopsi Internet yang masih rendah dilihat dari durasi online terutama dipengaruhi oleh biaya akses yang masih sangat mahal. Kualitas infrastruktur yang menyebabkan kecepatan akses lambat juga dilaporkan menjadi salah satu penghambat adopsi Internet di Indonesia, di samping kemampuan Bahasa Inggris yang secara umum masih lemah.

\subsection{Keterbatasan dan Saran}

Seperti halnya penelitian empiris lain, penelitian ini tidak lepas dari keterbatasan. Pertama, responden penelitian hanya dari kalangan mahasiswa. Meskipun mahasiswa adalah komunitas yang homogen dan karenanya menjadikan pembandingan antara dua kelompok jender cukup memberikan gambaran perbedaan, namun pelibatan responden dengan latar belakang yang lebih beragam akan memberikan gambaran yang lebih lengkap tentang perbedaan adopsi Internet antara laki-laki dan perempuan.

Kedua, model adopsi yang digunakan dalam penelitian ini tidak melibatkan variabel lain yang juga sangat mungkin mempengaruhi adopsi Internet selain tingkat manfaat dan kemudahan yang dipersepsikan. TAM dalam banyak literatur dianggap sebagai model yang sangat sederhana untuk memberikan prediksi intensi adopsi, namun tidak memberikan penjelasan yang cukup lengkap karena kesederhaannnya. Pelibatan variabel lain dalam model sangat mungkin memberikan daya penjelasan (explanation power) yang lebih baik.

\subsection{Implikasi}

Temuan-temuan penelitian ini memberikan beberapa implikasi terhadap program yang dirancang untuk meningkatkan melek teknologi informasi di Indonesia, terutama di kalangan perempuan. Karena secara umum, kemampuan teknis perempuan lebih rendah dibandingkan laki-laki, maka program yang 
dirancang harus mempertimbangkan kesenjangan ini. Hal yang serupa juga untuk pengguna laki-laki yang kemampuan Bahasa Inggrisnya cenderung lebih rendah.

Dari sisi yang lain, penyediaan konten dalam Bahasa Indonesia juga perlu digalakkan untuk menarik semakin banyak pengguna yang mempunyai kemampuan bahasa asing yang lemah dan memberikan peluang yang lebih untuk penyebaran informasi dan pengetahuan. Dengan demikian manfaat Internet semakin dapat dirasakan. Seperti telah diketahui, ketersediaan konten dalam Bahasa Indonesia di Internet sangat terbatas.

\section{PUSTAKA}

[1] Abbott, J. P. (2001) Democracy@internet.asia? The Challenges to the Emancipatory Potential of the Net: Lessons from China and Malaysia. Third World Quarterly, Vol. 22, No. 1, 99-114.

[2] Ajzen, I., dan Fishbein, M. (1980) Understanding attitude and predicting social behavior, Prentice-Hall, Englewood Cliffs, NJ.

[3] APJII (2005). Statistik APJII. Diakses pada 26 September, 2005 dari http://www.apjii.or.id

[4] Basuni, D. F., et al. (2001). Indikasi Teknologi Informasi dan Komunikasi 2001. Diakses pada 15 Agustus, 2002 dari http://www.inn.bppt.go.id/Siti2001/ default.htm

[5] Davis, F. D., Bagozzi, R. P., dan Warshaw, P. R. (1989) User acceptance of computer technology: comparison of two theoretical models. Management Science, Vol. 35, No. 8, 982-1003.

[6] Du, X. (1999) Internet Diffusion and Usage in China. Promotheus, Vol. 17, No. 4, 405-420.

[7] Fountain, J. E. (2000) Constructing the information society: women, information technology, and design. Technology in Society, Vol. 22, 45-62.

[8] Furuholt, B., Wahid, F., dan Kristiansen, S. (2004) Cyber Cultures: The Use of Internet Café in Indonesia.

[9] Gefen, D., dan Straub, D. W. (1997) Gender differences in the perception and use of e-mail: the expressive dmension and critique of andogyny scales. MIS Quarterly, Vol. 21, No. 4, 375-400.

[10] Greenspan, R. (2004). Europe, U.S. on Different Sides of the Gender Divide. Diakses pada 7 Maret, 2004 dari http://www.clickz.com/stats/big_picture/ demographics/article.php/3095681

[11] GVU (1998). GVU's WWW user surveys. Diakses pada 27 Maret, 2004 dari http://www.gvu.gatech.edu/user_surveys/

[12] Harrison, D. A., Mykytyn, P. P., Jr., dan Riemenschneider, C. K. (1997) Executive decisions about adoption of information technology in small business: theory and empirical tests. Information System Research, Vol. 8, No. 2, 171-195.

[13] Hofstede, G. (1997) Cultures and Organizations: Software of the Mind, McGrawHill, New York.

[14] Kiiski, S., dan Pohjola, M. (2002) Cross-country diffusion of the Internet. Information Economics and Policy, Vol. 14, 297-310. 
[15] Kristiansen, S., Furuholt, B., dan Wahid, F. (2005). Internet for development? Patterns of use among Internet café customers in Indonesia. Unpublished manuscript.

[16] La Ferle, C., Edwards, S. M., dan Mizuno, Y. (2002) Internet diffusion in Japan: cultural considerations. Journal of Advertising Research, Vol. March-April, 65-79.

[17] Larry, P., Foster, W., Wolcott, P., dan McHenry, W. (2002) The Internet in India and China. First Monday, Vol. 7, No. 10.

[18] Legris, P., Inghamb, J., dan Collerettec, P. (2003) Why do people use information technology? A critical review of the technology acceptance model. Information \& Management, Vol. 40, 191-204.

[19] Mathieson, K. (1991) Predicting user intention: comparing the technology acceptance model with the theory of planned behavior. Information Systems Research, Vol. 2, No. 3, 173-191.

[20] Minton, H. L., dan Schneider, F. W. (1971) Differential Psychology, Waveland Press, Prospect Heights, IL.

[21] Nunally, J. C. (1978) Psychometric Theory, McGraw-Hill, New York.

[22] Plouffe, C. R., Hulland, J. S., dan Vandenbosch, M. (2001) Richness versus parsimony in modeling technology adoption decisions - understanding merchant adoption of a smart card-based payment system. Information Systems Research, Vol. 12, No. 2, 208-222.

[23] Purbo, O. W. (2002) Getting Connected: The Struggle to Get Indonesia Online. Inside Indonesia, No. 72, 14-16.

[24] Rogers, E. M. (1995) Diffusion of innovations (4 ed.), The Free Press, New York.

[25] Scott, A., Semmens, L., dan Willoughby, L. (1999) Women and the Internet: the natural history of a research project. Information, Communication \& Society, Vol. 2, No. 4, 541-565.

[26] Taylor, S., dan Todd, P. (1995) Understanding information technology usage: a test of competing model. Information Systems Research, Vol. 6, No. 2, 144-176.

[27] Venkatesh, V., dan Morris, M. G. (2000) Why dont men ever stop to ask for directions? Gender, social influence, and their role in technology acceptance and usage behavior? MIS Quarterly, Vol. 24, No. 1, 115-139.

[28] Warf, B., dan Grimes, J. (1997) Counterhegemonic Discourses and the Internet. Geographical Review, Vol. 87, No. 2, 259-274.

[29] Wolcott, P., Press, L., McHerry, W., Goodman, S., dan Foster, W. (2001) A framework for assessing the global diffusion of the Internet. Journal of the Association for Information Systems, Vol. 2, No. 6.

[30] Zoeltom, A., dan Rozy, F. (2004, 11 Februari). Membuat Perempuan Melek ICT. Warta Ekonomi, Vol. 16, 90-94. 